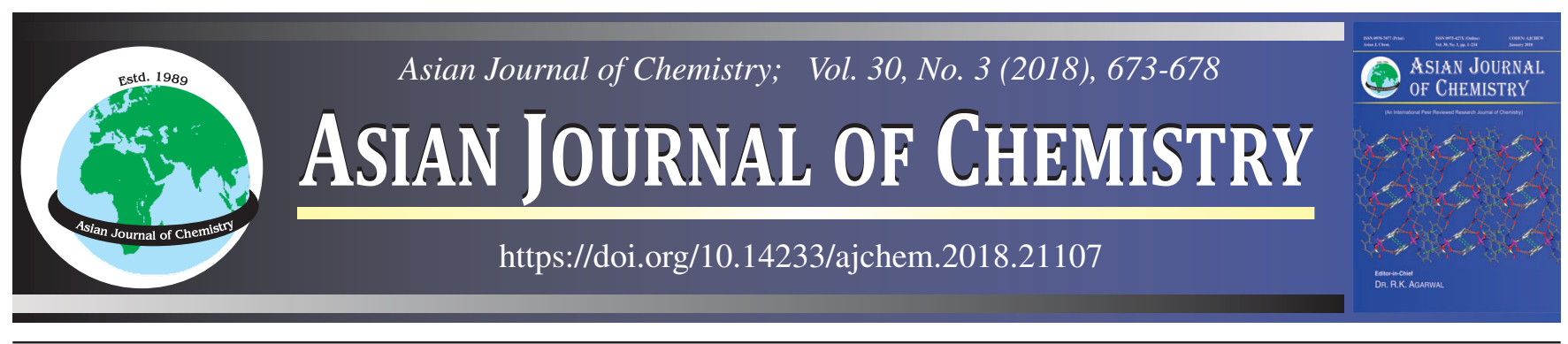

\title{
Seasonal Variation of Trace and Heavy Metals in Agricultural Soils around Tummalapalle Uranium Mining Site
}

\section{S. Kulavardhana Reddy ${ }^{1}$, C. Sivanandha Reddy ${ }^{1}$ and Gopireddy Venkata Subba Reddy2,*}

${ }^{1}$ Faculty of Chemistry, Jawaharlal Nehru Technological University Anantapur, Anantapuramu-515 002, India

${ }^{2}$ Department of Chemistry, JNTUA College of Engineering (Autonomous), Pulivendula-516 390, India

*Corresponding author: E-mail: gopireddy.chemistry@jntua.ac.in

Received: 27 October 2017;

Accepted: 27 December 2017;

Published online: 31 January 2018;

AJC-18764

Assessment of seasonal variation in concentration of trace and heavy metals e.g., B, Ca, Cu, Fe, K, Mg, Mn, Mo, P, Zn, As, Cd, Pb, Se and $\mathrm{Tl}$ in agricultural fields (soils) around Tummalapalle uranium mining site, Pulivendula, Kadapa district, have been undertaken up during two major seasons of Andhra Pradesh. This was carried out mainly to assess the environmental pollution status of the soil around Tummalapalle uranium mining site. The soil samples were analyzed for trace and heavy metals using inductive coupled plasma optical emission spectroscopy (ICP-OES). The mean concentration range of B: 0.087-0.21 mg/kg; Ca: 40.43-119.9 mg/kg; Cu: 2.16-8.17 mg/kg; | Fe: 103.2-222 mg/kg; K: 62.15-151.1 mg/kg; Mg: 25.7-46.95 mg/kg; Mn: 3.37-5.84 mg/kg; Mo: 2.58-5.41 mg/kg; P: 0.59-2.44 mg/kg; $\mathrm{Zn}: 0.14-0.29 \mathrm{mg} / \mathrm{kg}$; Pb: 0.049-0.078 mg/kg found during pre-monsoon season period and B: 0.22-0.42 mg/kg; Ca: 78.7-124.62 mg/kg; $\mathrm{Cu}: 2.48-6.42 \mathrm{mg} / \mathrm{kg}$; Fe: $194-360 \mathrm{mg} / \mathrm{kg} ; \mathrm{K}: 72.64-134.4 \mathrm{mg} / \mathrm{kg} ; \mathrm{Mg}: 32.72-56 \mathrm{mg} / \mathrm{kg} ; \mathrm{Mn}: 1.76-2.5 \mathrm{mg} / \mathrm{kg} ; \mathrm{Mo}: 0.11-0.14 \mathrm{mg} / \mathrm{kg} ; \mathrm{P}$ : 3.03-8 mg/kg; Zn: 0.3-0.16 mg/kg; and Pb: 0.02-0.12 mg/kg assessed in post monsoon season. During the assessment, As, Cd, Se and Tl could not found in both seasons.

Keywords: Trace and heavy metals, Environmental pollution, Seasonal variation, Uranium mining area.

ᄂ - - - - - - - - - - - - - - - - - - - - - - - - - - - -

\section{INTRODUCTION}

Soils may become contaminated by the accumulation of heavy metals and metalloids through emissions from the rapidly expanding industrial areas, mine tailings, disposal of high metal wastes, leaded gasoline and paints, land application of fertilizers, animal manures, sewage sludge, pesticides, wastewater irrigation, coal combustion residues, spillage of petrochemicals and atmospheric deposition [1,2]. The intensification of mining operations, crushing, washing and smelting of the ore were performed close to the mining site and the amount of mining residues deposited in soils in and around the mining site. The heaviest deposition of airborne metal particles occurs in the vicinity of mines, smelters and metal processing/heavy engineering works, which constitute the main emission sources. But many of the particles are very fine that they can be carried to enormous distances by the wind [3].

Heavy metal contamination of soil may pose risks and hazards to humans and the ecosystem through direct ingestion or contact with contaminated soil, the food chain (soil-planthuman or soil-plant-animal-human), drinking of contaminated ground water, reduction in food quality (safety and marketability) via phytotoxicity, reduction in land usability for agricultural production causing food insecurity and land tenure problems [4].
Soil is not only the key nutrient-bearing environment for plant life, but also a supplier of many pollutants to plants, as plants can uptake toxic substances through their roots from soils [5]. The plants grown in a polluted environment can accumulate trace elements at high concentrations and may serve as a main pathway for transferring metals into the food chain. These plants then pose a serious risk to consumers [6].

The main objective of this study is to assess the status of seasonal variation, distribution and dispersion of trace and heavy metals in agricultural fields in the vicinity of Tummalapalle uranium mining area, Andhra Pradesh, India.

\section{EXPERIMENTAL}

Study area: The study area and uranium underground mining site is located in and around Tummalapalle village, YSR District, Andhra Pradesh, India. The mining site is located between latitudes $14^{\circ} 18^{\prime} 36^{\prime \prime} \mathrm{N}$ and $14^{\circ} 20^{\prime} 20^{\prime \prime} \mathrm{N}$ and longitudes $78^{\circ} 15^{\prime} 16^{\prime \prime} \mathrm{E}$ and $78^{\circ} 18^{\prime} 03.3 \mathrm{E}$ according to survey of Indian Toposheet Nos. $57 \mathrm{~J} / 3$ and $57 \mathrm{~J} / 7$. The details of selected agricultural (five) fields are located around mining area and locations are given in Table-1.

Collection of samples: The soil samples were collected seasonally (pre and post monsoon) from five selected agricul- 
TABLE-1

LOCATION NAMES, LATITUDES/LONGITUDES AND DISTANCE FROM THE MINING AREA

\begin{tabular}{clccc}
\hline S. No. & \multicolumn{1}{c}{ Location } & Distance from the mining site $(\mathrm{km})$ & Latitude & Longitude \\
\hline 1 & Mabbuchinthala palle (site I) & 5 & $14^{\circ} 20^{\prime} 34.92^{\prime \prime} \mathrm{N}$ & $78^{\circ} 14^{\prime} 40.32^{\prime \prime} \mathrm{E}$ \\
2 & Mabbuchinthala palle (site II) & 7 & $14^{\circ} 19^{\prime} 45.84^{\prime \prime} \mathrm{N}$ & $78^{\circ} 14^{\prime} 17.76^{\prime \prime} \mathrm{E}$ \\
3 & Rachakunta palle (site III) & 2 & $14^{\circ} 18^{\prime} 39^{\prime \prime} 60^{\prime \prime} \mathrm{N}$ & $78^{\circ} 17^{\prime} 48.30^{\prime \prime} \mathrm{E}$ \\
4 & Bhumaiagari palle (site IV) & 3 & $14^{\circ} 19^{\prime} 24.54^{\prime \prime} \mathrm{N}$ & $78^{\circ} 18^{\prime} 03.48^{\prime \prime} \mathrm{E}$ \\
5 & Bhumaiagari palle (site V) & 8 & $14^{\circ} 19^{\prime} 37.74^{\prime \prime} \mathrm{N}$ & $78^{\circ} 19^{\prime} 12.60^{\prime \prime} \mathrm{E}$ \\
\hline
\end{tabular}

tural fields around Tummalapalle uranium mining site (Table-1). The soil samples were collected from a depth of $0-15 \mathrm{~cm}$ in selected crop fields. The collected soil samples were taken in polyethylene bags for transportation to the laboratory and shade dried in laboratory for 4 days, after then dried in an oven at $110{ }^{\circ} \mathrm{C}$ for about $4-5 \mathrm{~h}$ to remove the total moisture content in soil. The dried samples were crushed and grounded into $2 \mathrm{~mm}$ mesh size.

Sample preparation: $1 \mathrm{~g}$ of dry homogenized soil sample was digested with $10 \mathrm{~mL}$ conc. $\mathrm{HNO}_{3}$ and $70 \%$ conc. $\mathrm{HClO}_{4}$ for approximately 30-40 min using hotplate. After that the digested samples cooled to room temperature and then filtered into $100 \mathrm{~mL}$ volumetric flack using Whatman No.42 filter paper and made up to the mark with distilled water. The blank solution was also prepared in the same procedure [7].

Analysis of metals: The $\mathrm{pH}$ of soil samples was determined by using $\mathrm{pH}$ instrument (electrode method). The physicochemical properties such as $\mathrm{pH}$, texture, electrical conductivity (EC) and organic matter were done by using standard methods. All soil samples were analyzed using inductively coupled plasma-optical emission spectroscopy (ICP-OES; model Perkin Elmer 7000DV).

\section{RESULTS AND DISCUSSION}

Soil properties: Soil physical properties of texture, $\mathrm{pH}$, electrical conductivity (EC) and organic matter $(\mathrm{OM})$ were examined in selective agricultural fields around uranium mining site pre and post monsoon seasons by following standard protocols [8] and the experimental data are shown in Table-2.

The experimental analysis of soil samples collected from the nearby area of uranium mining site shows that there is moderate variation in the trace and heavy metals concentrations in pre and post monsoon seasons.

Table-2 represents the soil $\mathrm{pH}$ values slightly increase in post-monsoon (8.95-9.19) when compared to pre-monsoon season (7.95-8.08) due to increase in moisture levels in soil and leaching of some of minerals through rain since the study area is dolomite basin. The $\mathrm{pH}$ value of soil indicates that soil is moderately alkaline nature in both seasons. It impacts the trace metal solubility and greater retention of metals in soils. Therefore the alkaline nature of soil causes for increases the mobility of metals due to hydroxides precipitation, carbonates or insoluble organic complexes formation which may limit trace metal uptake and translocation into shoots [9]. The electrical conductivity ranges also increases in post-monsoon (0.47-0.60 $\mathrm{dS} \mathrm{^{-1 }}$ ) season when compared with pre-monsoon (0.43-0.51

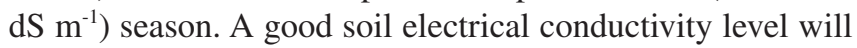
be somewhere above $0.2 \mathrm{dS} \mathrm{m}^{-1}$ and below $1.2 \mathrm{dS} \mathrm{m}^{-1}$ [10]. In this study the electrical conductivity values were found to within the range in both the seasons. The soil organic matter is increased slightly in post-monsoon season (0.40-0.91\%) when compared with pre-monsoon season $(0.29-0.90 \%)$. Soil texture will influences soil organic matter by which affects on plant growth (inputs) and protection from decomposition (outputs). The fine textured soils (clay loam) commonly contain higher amounts of organic matter than sandy soils [11]. The organic matter which will help to the healthy soil for sustainable for cropping system.

Metal concentration in soil: The soil samples were analyzed by using ICP-OES technique for trace and heavy metals estimation in selective agricultural fields and the evaluated data is shown in Table-3.

The various trace metal concentrations under investigation are found to in the range: B: $0.087-0.21 \mathrm{mg} / \mathrm{kg}$; Ca: 40.43$119.9 \mathrm{mg} / \mathrm{kg}$; Cu: 2.16-8.17 mg/kg; Fe: $103.2-222 \mathrm{mg} / \mathrm{kg}$; K: 62.15-151.1 mg/kg; Mg: 25.7-46.95 mg/kg; Mn: 3.37-5.84 $\mathrm{mg} / \mathrm{kg}$; Mo: $2.58-5.41 \mathrm{mg} / \mathrm{kg}$; P: 0.59-2.44 mg/kg; Zn: 0.14$0.29 \mathrm{mg} / \mathrm{kg}$; $\mathrm{Pb}: 0.049-0.078 \mathrm{mg} / \mathrm{kg}$ in pre-monsoon season and B: $0.22-0.42 \mathrm{mg} / \mathrm{kg}$; Ca: 78.7-124.62 mg/kg; Cu: $2.48-$ $6.42 \mathrm{mg} / \mathrm{kg}$; Fe: $194-360 \mathrm{mg} / \mathrm{kg}$; K: 72.64-134.4 mg/kg; Mg: $32.72-56 \mathrm{mg} / \mathrm{kg}$; Mn: $1.76-2.5 \mathrm{mg} / \mathrm{kg}$; Mo: 0.11-0.14 mg/kg; P: $3.03-8 \mathrm{mg} / \mathrm{kg}$; Zn: 0.3-0.16 mg/kg; and Pb: 0.02-0.12 mg/ $\mathrm{kg}$ in post monsoon season. During these two seasons As, Cd, $\mathrm{Se}$ and $\mathrm{Tl}$ could not found. The trend of mean concentrations of trace metals is: $\mathrm{Fe}>\mathrm{K}>\mathrm{Ca}>\mathrm{Mg}>\mathrm{Cu}>\mathrm{Mn}>\mathrm{Mo}>\mathrm{P}>$ $\mathrm{Zn}>\mathrm{B}>\mathrm{Pb} ; \mathrm{Fe}>\mathrm{K}>\mathrm{Ca}>\mathrm{Mg}>\mathrm{P}>\mathrm{Cu}>\mathrm{Mn}>\mathrm{B}>\mathrm{Zn}>\mathrm{Mo}$ $>\mathrm{Pb}$ in pre and post monsoon seasons. The literature and

TABLE-2

SOIL PHYSICAL PROPERTIES OF PRE-MONSOON AND POST-MONSOON SEASONS

\begin{tabular}{|c|c|c|c|c|c|c|c|c|}
\hline \multirow[b]{2}{*}{ Location } & \multicolumn{4}{|c|}{ Pre-monsoon } & \multicolumn{4}{|c|}{ Post-monsoon } \\
\hline & Texture & $\mathrm{pH}$ & $\begin{array}{l}\text { Electrical conduc- } \\
\text { tivity }\left(\mathrm{dS} \mathrm{m} \mathrm{m}^{-1}\right)\end{array}$ & $\begin{array}{c}\text { Organic } \\
\text { matter }(\%)\end{array}$ & Texture & $\mathrm{pH}$ & $\begin{array}{l}\text { Electrical conduc- } \\
\text { tivity }\left(\mathrm{dS} \mathrm{m} \mathrm{m}^{-1}\right)\end{array}$ & $\begin{array}{c}\text { Organic } \\
\text { matter }(\%)\end{array}$ \\
\hline Site I & Clay loam & 8.06 & 0.51 & 0.83 & Clay loam & 9.08 & 0.6 & 0.91 \\
\hline Site II & Sandy clay loam & 7.95 & 0.43 & 0.29 & Sandy clay loam & 8.95 & 0.52 & 0.56 \\
\hline Site III & Clay loam & 8.05 & 0.43 & 0.36 & Clay loam & 9.19 & 0.58 & 0.4 \\
\hline Site IV & Clay loam & 8.02 & 0.44 & 0.39 & Clay loam & 9.01 & 0.47 & 0.64 \\
\hline Site V & Clay loam & 8.08 & 0.48 & 0.9 & Clay loam & 9.12 & 0.53 & 0.87 \\
\hline Mean & - & 8.03 & 0.45 & 0.55 & - & 9.07 & 0.54 & 0.67 \\
\hline SD & - & 0.05 & 0.03 & 0.28 & - & 0.09 & 0.05 & 0.21 \\
\hline
\end{tabular}


TABLE-3

METAL CONCENTRATION IN SOIL ( $\mathrm{mg} / \mathrm{kg})$

\begin{tabular}{|c|c|c|c|c|c|c|c|c|c|c|c|c|c|c|c|}
\hline \multirow{2}{*}{ Location } & $\mathrm{B}$ & $\mathrm{Ca}$ & $\mathrm{Cu}$ & $\mathrm{Fe}$ & $\mathrm{K}$ & $\mathrm{Mg}$ & $\mathrm{Mn}$ & Mo & $\mathrm{P}$ & $\mathrm{Zn}$ & As & $\mathrm{Cd}$ & $\mathrm{Pb}$ & $\mathrm{Se}$ & $\mathrm{Tl}$ \\
\hline & \multicolumn{15}{|c|}{ Pre-monsoon } \\
\hline Site-I & 0.210 & 47.67 & 2.16 & 103.20 & 121.98 & 33.97 & 3.37 & 2.58 & 1.80 & 0.21 & 0 & 0 & 0.058 & 0 & 0 \\
\hline Site-II & 0.210 & 103.00 & 3.20 & 127.80 & 87.76 & 57.90 & 5.84 & 3.19 & 0.59 & 0.29 & 0 & 0 & 0.049 & 0 & 0 \\
\hline Site-III & 0.100 & 40.43 & 8.17 & 138.00 & 79.53 & 25.70 & 4.93 & 3.38 & 2.44 & 0.14 & 0 & 0 & 0.061 & 0 & 0 \\
\hline Site-IV & 0.092 & 53.42 & 6.21 & 222.00 & 62.15 & 26.80 & 4.41 & 5.41 & 2.02 & 0.22 & 0 & 0 & 0.078 & 0 & 0 \\
\hline Site-V & 0.087 & 119.90 & 5.18 & 160.90 & 151.10 & 46.95 & 4.25 & 3.82 & 2.35 & 0.24 & 0 & 0 & 0.070 & 0 & 0 \\
\hline Mean & 0.140 & 72.88 & 4.98 & 150.38 & 100.5 & 38.26 & 4.56 & 3.67 & 1.84 & 0.22 & 0 & 0 & 0.060 & 0 & 0 \\
\hline \multirow[t]{2}{*}{ SD } & 0.060 & 36.00 & 2.39 & 45.08 & 35.68 & 13.86 & 0.90 & 1.06 & 0.74 & 0.05 & 0 & 0 & 0.010 & 0 & 0 \\
\hline & \multicolumn{15}{|c|}{ Post-monsoon } \\
\hline Site-I & 0.36 & 94.48 & 5.17 & 360.00 & 134.40 & 42.24 & 2.24 & 0.11 & 3.45 & 0.15 & 0 & 0 & 0.02 & 0 & 0 \\
\hline Site-II & 0.32 & 99.08 & 4.20 & 290.00 & 110.24 & 37.24 & 1.76 & 0.13 & 4.62 & 0.13 & 0 & 0 & 0.09 & 0 & 0 \\
\hline Site-III & 0.30 & 124.62 & 3.59 & 194.00 & 96.50 & 33.08 & 1.96 & 0.14 & 3.24 & 0.16 & 0 & 0 & 0.11 & 0 & 0 \\
\hline Site-IV & 0.22 & 108.72 & 2.48 & 296.00 & 72.64 & 56.00 & 2.24 & 0.11 & 3.03 & 0.13 & 0 & 0 & 0.12 & 0 & 0 \\
\hline Site-V & 0.42 & 78.70 & 6.42 & 201.12 & 119.60 & 32.72 & 2.50 & 0.14 & 8.00 & 0.30 & 0 & 0 & 0.10 & 0 & 0 \\
\hline Mean & 0.32 & 101.12 & 4.37 & 268.22 & 106.67 & 40.25 & 2.14 & 0.12 & 4.47 & 0.17 & 0 & 0 & 0.09 & 0 & 0 \\
\hline SD & 0.07 & 17.03 & 1.50 & 70.14 & 23.50 & 9.60 & 0.28 & 0.01 & 2.06 & 0.06 & 0 & 0 & 0.03 & 0 & 0 \\
\hline
\end{tabular}

various agencies specified standard limits of various trace and heavy metals are given in Table- 4 and the graphical representation of seasonal variation of trace and heavy metals concentration under investigation of selective sites are shown in Fig. 1.

The boron concentration levels in both pre and postmonsoon seasons are found in the range of $0.14-0.32 \mathrm{mg} / \mathrm{kg}$ which is below the literature value [12], which may leads to lowering of bioaccumulation of boron in vegetable plants. Boron concentration levels are increased in post monsoon season when compared to pre monsoon season in each and every field under investigation, but highly increased in site- $\mathrm{V}(0.42 \mathrm{mg} / \mathrm{kg})$. The increased value during post monsoon is an indicative of readiness of agricultural forming practices to be taken up by farmer.

The mean concentration levels of calcium in pre and post monsoon seasons are 72.88 and $101.12 \mathrm{mg} / \mathrm{kg}$, respectively. In post monsoon season, the calcium levels are increased in site I, site III and site IV but decreased in site II and site V when compared to pre monsoon season. The obtained calcium concentration levels are within the permissible limits compared to literature value [13] in all sites.

The highest mean concentration of copper is obtained in pre monsoon season $(4.98 \mathrm{mg} / \mathrm{kg})$ when compared to post monsoon season $(4.37 \mathrm{mg} / \mathrm{kg})$. But, the copper concentration levels are increased in post monsoon season at site I, site II and site V, decreased in site III and site IV. The experimental values compared with literature values [14-16] and found to within the limits in all selective fields.
The concentration levels of lead increased in post monsoon season compared to pre monsoon season in all studied sites, except site I. The mean concentration levels of lead during pre-monsoon season is $0.06 \mathrm{mg} / \mathrm{kg}$ and post monsoon season is $0.09 \mathrm{mg} / \mathrm{kg}$, but the concentration levels are found to less in all the investigated sites compared to literature values [14-16]. Therefore, there will not be any lead contamination.

Zinc concentration levels increased in post monsoon season at site III and V, but decreased in site I, II and IV compared to pre monsoon season. The mean concentrations of zinc during pre and post monsoon season are 0.22 and $0.17 \mathrm{mg} / \mathrm{kg}$. Therefore, the experimental values of zinc are lesser in all studied sites during pre and post monsoon seasons, when compared with literature values [14-16]. Therefore, zinc concentration is needed to improve for better bioaccumulation of plants.

Obtained mean concentration of iron in pre monsoon season is $150.38 \mathrm{mg} / \mathrm{kg}$ and post monsoon season is $268.22 \mathrm{mg} / \mathrm{kg}$. The iron concentration levels increased in post monsoon season when compared to pre monsoon season. These values are found to higher concentration in site IV \&V during pre-monsoon season and higher concentration during post-monsoon season in all the selected sites according to Awashthi [15] and rest of the sites under investigation both pre and post monsoon are found to within the permissible limits when compared with literature value [17].

The highest mean concentration of manganese was observed in pre monsoon season $4.56 \mathrm{mg} / \mathrm{kg}$ and lowest mean concen-

TABLE-4

STANDARD TRACE \& HEAVY METAL CONCENTRATION LIMITS AND LITERATURE VALUES IN SOIL (mg/kg)

\begin{tabular}{|c|c|c|c|c|c|c|c|c|c|c|c|c|}
\hline B & $\mathrm{Ca}$ & $\mathrm{Cu}$ & $\mathrm{Fe}$ & K & $\mathrm{Mg}$ & Mn & Mo & $\mathrm{P}$ & $\mathrm{Zn}$ & $\mathrm{Cd}$ & $\mathrm{Pb}$ & Ref. \\
\hline \multirow[t]{10}{*}{5} & & & & & & & & & & & & {$[12]$} \\
\hline & $2-400$ & & & & & & & & & & & [13] \\
\hline & & 140 & & & & & & & 300 & 3 & 300 & [14] \\
\hline & & $135-270$ & $75-150$ & & & & & & $300-600$ & $3.0-6.0$ & $250-500$ & [15] \\
\hline & & & 1000 & & & & & & & & & [17] \\
\hline & & 50 & & & & 80 & & & 200 & 3 & 300 & [16] \\
\hline & & & & & & & & $<10$ & & & & [18] \\
\hline & & & & $121-160$ & & & & & & & & [19] \\
\hline & & & & & & & $>10$ & & & & & [20] \\
\hline & & & & & 150.2 & & & & & & & [21] \\
\hline
\end{tabular}



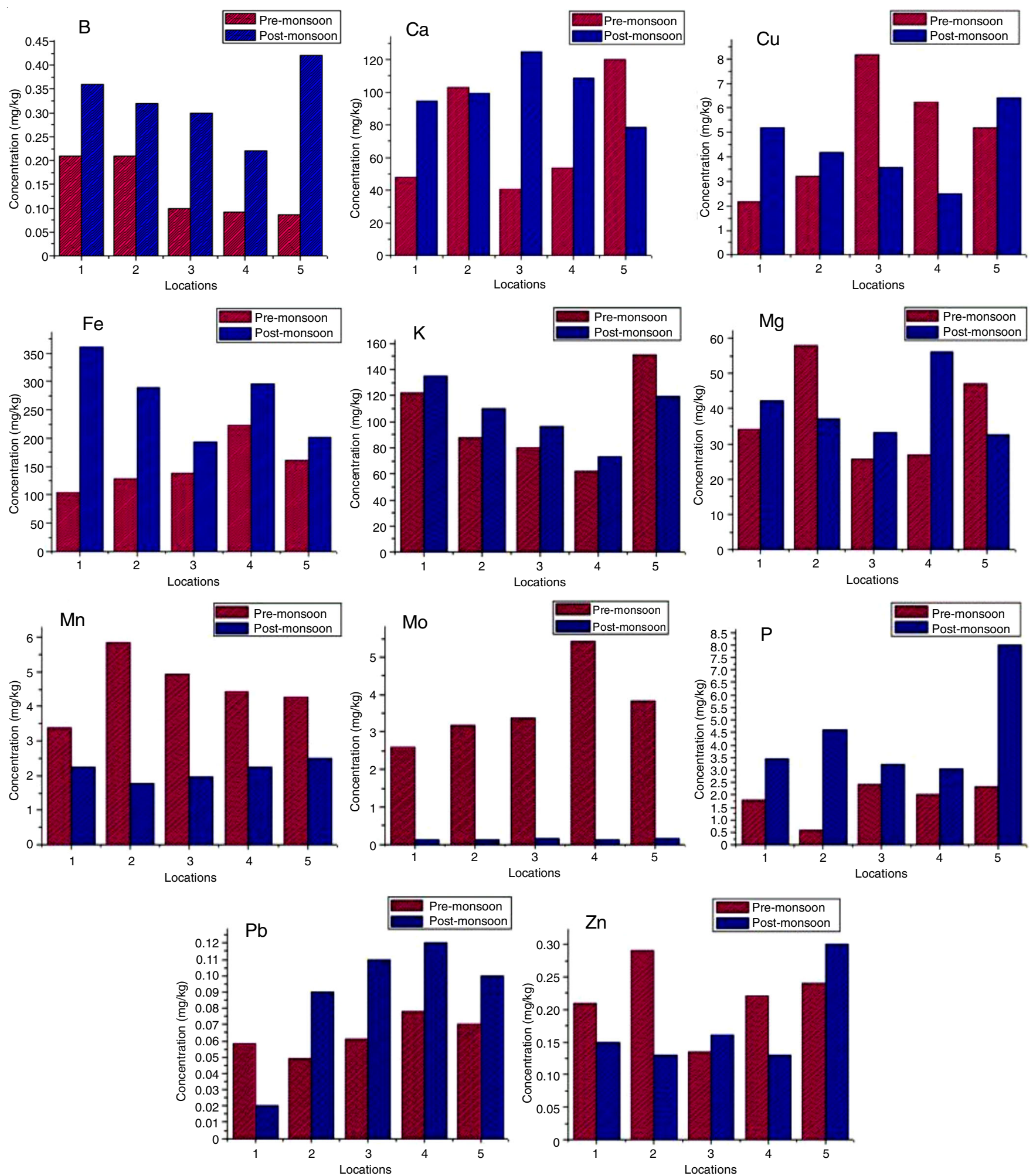

Fig. 1. Pre and post-monsoon seasons of trace and heavy metal concentration levels in soils

tration in post monsoon season $2.14 \mathrm{mg} / \mathrm{kg}$ at all studied sites. The manganese concentration levels decreased in post monsoon season when compared to pre monsoon season in all fields. Manganese concentrations are deficient in all investigated sites during pre and post monsoon seasons when compared to literature value [16].

The obtained phosphorus concentrations increased in post monsoon season compared to pre monsoon season in all studied sites. The mean concentration of phosphorus in pre monsoon is $1.84 \mathrm{mg} / \mathrm{kg}$ and post monsoon is $4.47 \mathrm{mg} / \mathrm{kg}$. The experimental values of phosphorus in all the investigated sites are found lower during pre and post monsoon seasons when compared to literature value [18] and it may be deficient.

The mean concentration of potassium in pre monsoon season is $100.5 \mathrm{mg} / \mathrm{kg}$ and post monsoon season is $106.67 \mathrm{mg} /$ $\mathrm{kg}$. Therefore, the mean concentration of potassium increased 
in post monsoon when compared to pre monsoon season. Potassium levels increased in all sites except site $\mathrm{V}$ in post monsoon season compared to pre monsoon season. The experimental values of potassium in the entire selective fields are found to within the limits when compared with literature value [19].

The mean concentration levels of molybdenum decreased in post monsoon season $0.12 \mathrm{mg} / \mathrm{kg}$ compared to pre monsoon season $3.67 \mathrm{mg} / \mathrm{kg}$ in all fields under investigation. Molybdenum concentration levels are good acceptable limits in pre and post monsoon season in all studied sites with respect to literature value [20].

The obtained magnesium mean concentration in pre monsoon season is $38.26 \mathrm{mg} / \mathrm{kg}$ and post monsoon season is 40.25 $\mathrm{mg} / \mathrm{kg}$. The $\mathrm{Mg}$ concentration levels increased in post monsoon season at site I, III and IV, but decrease in site II and IV when compared to pre monsoon season. The magnesium concentration levels are within the permissible levels as per literature value [21] and found to be good if its concentration is 150 $\mathrm{mg} / \mathrm{kg}$ and above. Therefore, experimental values in all the investigated sites are found to moderate level of concentration.

The cadmium, arsenic, selenium and thallium are not detected in all studied fields in both seasons.

Statistical analysis: In correlation analysis, bivariate method is being adopted to describe the relation between two different metals. The high correlation coefficient $(r=$ higher than 0.7$)$ shows strong correlation between two metals [22]. Pearson correlation coefficient data for trace metals in soils for pre and post monsoon season are shown in Table-5.

In pre monsoon season most of the metals [Cu $(-0.84), \mathrm{Fe}$ (-0.72), $\mathrm{P}(-0.78)$ and $\mathrm{Pb}(-0.81)]$ and post monsoon season $\mathrm{Ca}(-0.74), \mathrm{Mg}(-0.74)$ shown negatively correlated with boron, but $\mathrm{Cu}(0.99), \mathrm{K}(0.86), \mathrm{P}(0.78)$ and $\mathrm{Zn}(0.76)$ are strongly correlated with boron in post monsoon season. $\mathrm{Mg}(0.87)$ and $\mathrm{Zn}$ (0.74) strongly correlated with calcium in pre monsoon season, but $\mathrm{Cu}(-0.81)$ and $\mathrm{P}(-0.79)$ negatively correlated with calcium in post monsoon season. The $\mathrm{K}(0.85), \mathrm{P}(0.8)$ and $\mathrm{Zn}$ (0.79) strongly correlated with copper in post monsoon season; none of the trace metal under investigation correlates with copper in pre monsoon season. The Fe strongly correlated with $\mathrm{Mo}(0.99)$ and $\mathrm{Pb}(0.85)$ in pre monsoon season, but the same Mo (-0.89) metal negatively correlate with iron in post monsoon season. The Potassium doesn't correlate with any metals in both seasons, but $\mathrm{Pb}(-0.81)$ negatively correlate with $\mathrm{K}$ in post monsoon season. $\mathrm{Zn}(0.85)$ strongly correlate with $\mathrm{Mg}$ and negatively correlate with $\mathrm{P}(-0.71)$ in pre monsoon season and Mo (-0.86) negatively correlate with $\mathrm{Mg}$ in post monsoon season. Zn (0.7) strongly correlate with $\mathrm{Mn}$ in post monsoon season, doesn't correlate any metal in pre monsoon season. $\mathrm{Pb}(0.83)$ strongly correlate with Mo in pre monsoon season, but none of trace metal correlate with Mo in post monsoon season. The $\mathrm{Zn}$ (0.91) strongly correlate with $\mathrm{P}$ in post monsoon season.

\section{Conclusion}

The present study has generated data on trace and heavy metals in agricultural soils located in and around uranium mining site. The concentration levels of trace and heavy metals observed are comparable with literature values from various regions of the globe and standard agencies. The concentration trends of various measured trace and heavy metals in pre and post monsoon seasons at agricultural soils is in the order of $\mathrm{Fe}$ $>\mathrm{K}>\mathrm{Ca}>\mathrm{Mg}>\mathrm{Cu}>\mathrm{Mn}>\mathrm{Mo}>\mathrm{P}>\mathrm{Zn}>\mathrm{B}>\mathrm{Pb}$ and $\mathrm{Fe}>$ $\mathrm{K}>\mathrm{Ca}>\mathrm{Mg}>\mathrm{P}>\mathrm{Cu}>\mathrm{Mn}>\mathrm{B}>\mathrm{Zn}>\mathrm{Mo}>\mathrm{Pb}$. Therefore,

\begin{tabular}{|c|c|c|c|c|c|c|c|c|c|c|c|}
\hline \multicolumn{12}{|c|}{$\begin{array}{c}\text { TABLE-5 } \\
\text { PEARSON CORRELATION COEFFICIENTS (r) DATA OF TRACE AND HEAVY }\end{array}$} \\
\hline & $\mathrm{B}$ & $\mathrm{Ca}$ & $\mathrm{Cu}$ & $\mathrm{Fe}$ & $\mathrm{K}$ & $\mathrm{Mg}$ & $\mathrm{Mn}$ & Mo & $\mathrm{P}$ & $\mathrm{Zn}$ & $\mathrm{Pb}$ \\
\hline & \multicolumn{11}{|c|}{ Pre monsoon season } \\
\hline $\mathrm{B}$ & 1 & & & & & & & & & & \\
\hline $\mathrm{Ca}$ & 0.009 & 1 & & & & & & & & & \\
\hline $\mathrm{Cu}$ & -0.84 & -0.29 & 1 & & & & & & & & \\
\hline $\mathrm{Fe}$ & -0.72 & 0.001 & 0.51 & 1 & & & & & & & \\
\hline $\mathrm{K}$ & 0.066 & 0.56 & -0.41 & -0.41 & 1 & & & & & & \\
\hline $\mathrm{Mg}$ & 0.46 & $0.87 *$ & -0.56 & -0.32 & 0.4 & 1 & & & & & \\
\hline $\mathrm{Mn}$ & 0.064 & 0.34 & 0.23 & 0.052 & -0.45 & 0.48 & 1 & & & & \\
\hline Mo & -0.69 & -0.028 & 0.5 & $0.99^{*}$ & -0.46 & -0.33 & 0.06 & 1 & & & \\
\hline $\mathrm{P}$ & -0.78 & -0.33 & 0.64 & 0.3 & 0.2 & -0.71 & -0.55 & 0.27 & 1 & & \\
\hline $\mathrm{Zn}$ & 0.45 & $0.74 *$ & -0.67 & 0.015 & 0.21 & $0.85^{*}$ & 0.31 & 0.02 & -0.76 & 1 & \\
\hline \multirow[t]{2}{*}{$\mathrm{Pb}$} & -0.81 & -0.12 & 0.49 & $0.85^{*}$ & -0.067 & -0.54 & -0.42 & $0.83^{*}$ & 0.68 & -0.24 & 1 \\
\hline & \multicolumn{11}{|c|}{ Post monsoon season } \\
\hline $\mathrm{B}$ & 1 & & & & & & & & & & \\
\hline $\mathrm{Ca}$ & -0.74 & 1 & & & & & & & & & \\
\hline $\mathrm{Cu}$ & $0.99 *$ & -0.81 & 1 & & & & & & & & \\
\hline $\mathrm{Fe}$ & -0.2 & -0.14 & -0.14 & 1 & & & & & & & \\
\hline K & $0.86^{*}$ & -0.61 & $0.85^{*}$ & 0.23 & 1 & & & & & & \\
\hline $\mathrm{Mg}$ & -0.74 & 0.17 & -0.64 & 0.59 & -0.57 & 1 & & & & & \\
\hline $\mathrm{Mn}$ & 0.39 & -0.58 & 0.48 & -0.088 & 0.16 & 0.13 & 1 & & & & \\
\hline Mo & 0.46 & -0.008 & 0.37 & -0.89 & 0.1 & -0.86 & -0.12 & 1 & & & \\
\hline $\mathrm{P}$ & $0.78 *$ & -0.79 & $0.8^{*}$ & -0.47 & 0.4 & -0.54 & 0.5 & 0.57 & 1 & & \\
\hline $\mathrm{Zn}$ & $0.76^{*}$ & -0.66 & $0.79 *$ & -0.58 & 0.36 & -0.52 & $0.7^{*}$ & 0.57 & $0.91 *$ & 1 & \\
\hline $\mathrm{Pb}$ & -0.43 & 0.34 & -0.45 & -0.69 & -0.81 & 0.075 & -0.088 & 0.44 & 0.11 & 0.11 & 1 \\
\hline
\end{tabular}

*Indicate that good correlation between two metals. 
all the metals are present in acceptable limits during pre and post monsoon season compared with standards and literature values. So, all the selected sites are found to good for starting of forming practice and better crop production. The $\mathrm{Zn}$ metal strongly correlates with $\mathrm{Ca}, \mathrm{Mg}, \mathrm{B}, \mathrm{Cu}, \mathrm{Mn}$ and $\mathrm{P}$ during pre and post monsoon season; $\mathrm{K}$ and $\mathrm{P}$ strongly correlate with $\mathrm{B}$ and $\mathrm{Cu}$ during post monsoon season. Some of the metals negatively correlate like $\mathrm{Cu}, \mathrm{Fe}$ and $\mathrm{Pb}$ with $\mathrm{B}, \mathrm{Ca}$ and $\mathrm{K}$ during pre and post monsoon seasons.

\section{ACKNOWLEDGEMENTS}

The authors acknowledged to TEQIP-II, MHRD, Government of India for providing the financial assistance in the form of research assistanceship to carry out this research work.

\section{REFERENCES}

1. S. Khan, Q. Cao, Y.M. Zheng, Y.Z. Huang and Y.G. Zhu, Environ. Pollut., 152, 686 (2008); https://doi.org/10.1016/j.envpol.2007.06.056.

2. M.K. Zhang, Z.Y. Liu and H. Wang, Commun. Soil Sci. Plant Anal., 41, 820 (2010);

https://doi.org/10.1080/00103621003592341.

3. S. Iram, I. Ahmad and D. Stuben, Pak. J. Bot., 41, 885 (2009).

4. M.J. McLaughlin, B.A. Zarcinas, D.P. Stevens and N. Cook, Commun. Soil Sci. Plant Anal., 31, 1661 (2000); https://doi.org/10.1080/00103620009370531.

5. S.P. Kayastha, Sci. World, 12, 48 (2015); https://doi.org/10.3126/sw.v12i12.13597.

6. B. Alloway, A.P. Jackson and H. Morgan, Sci. Total Environ., 91, 223 (1990);

https://doi.org/10.1016/0048-9697(90)90300-J.
7. N. Amin and T. Ahmad, RSC Adv., 5, 14322 (2015); https://doi.org/10.1039/C4RA14957B.

8. G. Estefan, R. Sommer and J. Ryan, Soil, Plant and Water AnalysisICARDA, edn 3, pp. 1-244 (2013).

9. C.J. Smith, P. Hopmans and F.J. Cook, Environ. Pollut., 94, 317 (1996); https://doi.org/10.1016/S0269-7491(96)00089-9.

10. J. Kumar Varma, A. Sharma and K.K. Paramanick, Int. J. Appl. Sci. Eng. Res., 4, 321 (2015).

11. R. Mouhamad, A. Atiyah, R. Mohammad and M. Iqbal, Int. Sci. Org, 1, 22 (2015)

12. A. Sasmaz, Int. J. Phytoremed., 10, 302 (2008); https://doi.org/10.1080/15226510802096119.

13. P. Akenga, A. Salim, A. Onditi, A. Yusuf and W. Waudo, IOSR J. Appl. Chem., 7, 34 (2014); https://doi.org/10.9790/5736-07713441.

14. EU, Heavy Metals in Wastes (European Commission DG ENV. E3 Report) (2002); http://ec.europa.eu/environment/waste/studies/pdf/heavy metalsreport.pdf.

15. S.K. Awashthi, Prevention of Food Adulteration Act No. 37 of 1954, Central and State Rules as Amended for 1999, Ashoka Law House, New Delhi (2000)

16. USEPA, Risk-based Concentration Table, United State Environmental Protection Agency, Washington, DC (2010).

17. A. Kabata-Pendias and H. Pendias, Trace Elements in Soils and Plants, CRC Press, Boca Raton, FL, edn 3, pp. 413 (2001).

18. FAO, A Framework for Land Evaluation, FAO Bulletin 32, FAO/UNESCO, France (1976).

19. D.E. Kaiser, C.J. Rosen and J.A. Lamb, Nutrient Management, University of Minnesota, pp. 1-9 (2016); http://www.extension.umn.edu/agriculture/nutrient-management.

20. P.L. Smedley and D.G. Kinniburgh, Appl. Geochem., 84, 387 (2017); https://doi.org/10.1016/j.apgeochem.2017.05.008.

21. A. Mehlich, Commun. Soil Sci. Plant Anal., 9, 477 (1978); https://doi.org/10.1080/00103627809366824.

22. M.S.R. Sharma and N.S. Raju, Int. Res. J. Environ. Sci., 2, 22 (2013). 